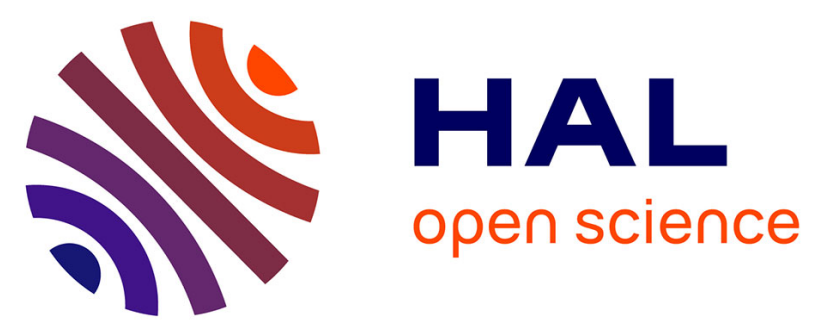

\title{
Changes in aliphatic hydrocarbon tracer composition during the digestive process of the marine worm Nereis virens. Preliminary results
}

Franck Gilbert, Georges Stora, Gaston Desrosiers, Jean-Pierre Gagne, Bruno Deflandre, Jean-Claude Bertrand

\section{To cite this version:}

Franck Gilbert, Georges Stora, Gaston Desrosiers, Jean-Pierre Gagne, Bruno Deflandre, et al.. Changes in aliphatic hydrocarbon tracer composition during the digestive process of the marine worm Nereis virens. Preliminary results. Chemosphere, 1998, vol. 36, pp. 553-560. 10.1016/S00456535(97)00358-5 . hal-00777965

\section{HAL Id: hal-00777965 https://hal.science/hal-00777965}

Submitted on 18 Jan 2013

HAL is a multi-disciplinary open access archive for the deposit and dissemination of scientific research documents, whether they are published or not. The documents may come from teaching and research institutions in France or abroad, or from public or private research centers.
L'archive ouverte pluridisciplinaire HAL, est destinée au dépôt et à la diffusion de documents scientifiques de niveau recherche, publiés ou non, émanant des établissements d'enseignement et de recherche français ou étrangers, des laboratoires publics ou privés. 


\title{
CHANGES IN ALIPHATIC HYDROCARBON TRACER COMPOSITION DURING THE DIGESTIVE
}

PROCESS OF THE MARINE WORM NEREIS VIRENS. PRELIMINARY RESULTS.

\author{
$\underline{\text { F. GILBERT }}^{\text {a,b }}$, G. STORA b ${ }^{\text {, G. DESROSIERS a }}$, J-P. GAGNE a, B. DEFLANDRE a \\ and J-C. BERTRAND $b$
}

\begin{abstract}
a Centre d'Océanographie de Rimouski, Département d'Océanographie, Université du Québec à Rimouski, 310 allée des Ursulines, Rimouski (Québec) G5L 3A1, Canada

b Laboratoire d'Océanographie et de Biogéochimie, Centre d'Océanologie de Marseille (OSU), Université de la Méditerranée, UMR n ${ }^{\circ}$ 6535, Campus de Luminy - Case 901, 13228 Marseille Cedex 9, France (Corresponding address)
\end{abstract}

Abstract : In the laboratory, marine worms were fed with a mixture of algae and several aliphatic hydrocarbons for 15 days. By comparing hydrocarbons in food and in faeces, it appeared that the worm's digestive process led to changes in the distribution of the $n$-alkanes mixture. These changes were different from those only due to physical processes in the experimental conditions, indicating that marine worm feeding could substantially affect the fate of hydrocarbons in the sedimentary marine ecosystem.

In the sediments, a number of biologically mediated processes could affect the cycling of hydrocarbons ${ }^{1,2}$. Among these processes, bioturbation, which can be defined as the stirring or movement of sediments by the activity of benthic organisms, and more particularly worms, plays an important role in the vertical redistribution of hydrocarbons in the sedimentary column ${ }^{3,4}$. Moreover, by modifying the chemical and microbial hydrocarbon environment, bioturbation may enhance the subsequent degradation of hydrocarbons compared to non-bioturbated sediments $5-8$ and extend it throughout the whole depth of bioturbated sediment depth ${ }^{9}$. However, if hydrocarbon redistribution is principally the result of particle transport induced by macrofauna during various activities (e.g. tube and burrow construction), it may also be realized through the 
faeces production process ${ }^{1}$. In areas of intensive reworking, where surface sediments are ingested several times a year ${ }^{10}$, passage through the gut exposes sorbed hydrocarbons to a harsh chemical and active microbiological environment ${ }^{11}$. If the metabolization of polycyclic aromatic hydrocarbons $7,12-14$ by worms has been demonstrated, little information is available on the uptake of aliphatic hydrocarbons ${ }^{3}$ by worms and their fate through the digestion process. A laboratory experiment has been carried out in order to investigate the fate of a mixture of aliphatic hydrocarbons ingested by the marine worm Nereis virens which is widely distributed in estuarine ecosystems. In this paper, we present the preliminary results obtained.

\section{EXPERIMENTAL}

- Collection of polychaetes and experimental setup: Twenty adult Nereis virens individuals with an average weight of $3.16 \pm 0.29 \mathrm{~g}($ mean $\pm \mathrm{SE}, n=20)$ were randomly collected in the tidal zone of l'Anse à l'Orignal (Bic, Québec) in November 1996. They were divided into 4 groups and placed in 4 containers $(50 \mathrm{~cm} \times 25 \mathrm{~cm} \times 5$ $\mathrm{cm})$. Each container was separated into 5 sections, and in each section a worm was placed in a horizontal glass tube (length: $19 \mathrm{~cm}$; i. d.: $0.7 \mathrm{~cm}$ ). The containers were filled with filtered seawater which was kept aerated by a small aquarium pump and maintained at constant temperature $\left(15^{\circ} \mathrm{C}\right)$ on a $12 \mathrm{~h}$ light $: 12 \mathrm{~h}$ dark cycle. Sea water was replaced each day. Worms were acclimated to the experimental conditions during 7 days (Figure 1). For the same period, the animals were not fed in order to clear their gut.

- Polychaetes feeding: Experimental food was prepared from individual portions of fresh algae Enteromorpha spp. $(13.9 \pm 1.7 \mathrm{mg}$; mean $\pm \mathrm{SE}, n=304)$ doped with hydrocarbon tracer $(3.6 \pm 0.2 \mathrm{mg}$; mean $\pm \mathrm{SE}, n=304)$ containing a mixture of eight $n$-alkanes $\left(n-\mathrm{C}_{14}, n-\mathrm{C}_{15}, n-\mathrm{C}_{17}, n-\mathrm{C}_{18}, n-\mathrm{C}_{22}, n-\mathrm{C}_{23}, n-\mathrm{C}_{28}\right.$ and $n$ - $\left.\mathrm{C}_{29}\right)$, one isoprenoid alkane (pristane) and one cyclic alkane (androstane). These hydrocarbons were wrapped inside a fresh leaf of algae to form a small pellet preserved frozen to $-20^{\circ} \mathrm{C}$ until feeding to the marine worm. This small solid pellet is stable for a few minutes in water and can therefore be used as feed for the marine worm.

At the beginning of the experiment, both experimental tubes and sections were cleaned and the sea water replaced. Then, at the start of the dark period, each worm was individually fed with a food portion, which was positioned at the end of the tube towards which the worm's head was pointing. In the following 10 seconds, the food portion was picked up by the worm. After 2, 4, 8, 12 and 24 hours ${ }^{15}$, the faeces of the five individual worms living in each separate container were sampled in the glass tubes and individual sections, regrouped, weighed and frozen before analysis. After collection of the $24 \mathrm{~h}$-faeces, the thin mucous layer with which inhabited tubes were coated was also collected, weighed and frozen. The tubes and sections were then cleaned 
by collecting the food residues, and the sea water was replaced. A new food portion was then given to each worm. During the experiment, worms were fed 15 times.

\section{Food portion preparation}

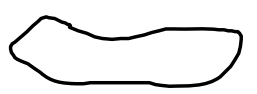

Fresh algae leaf (Enteromorpha spp.)

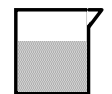

Hydrocarbon mixing

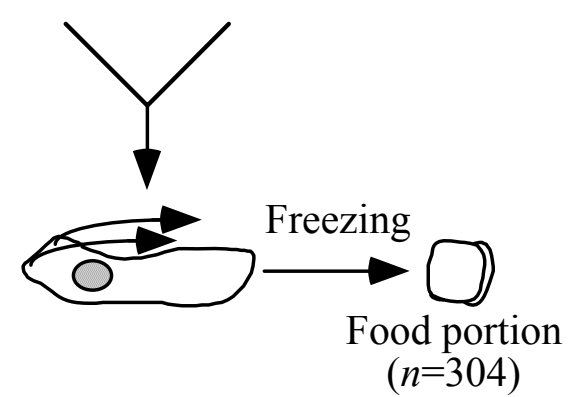

\section{Controls}<smiles>C1=CCCC1</smiles>

Food portions $(n=4)$ placed $24 \mathrm{~h}$ in container without worm under experimental conditions<smiles>[CH]1CC1</smiles>

"24h-Control" ( $n=4)$

\section{Acclimatation phase}

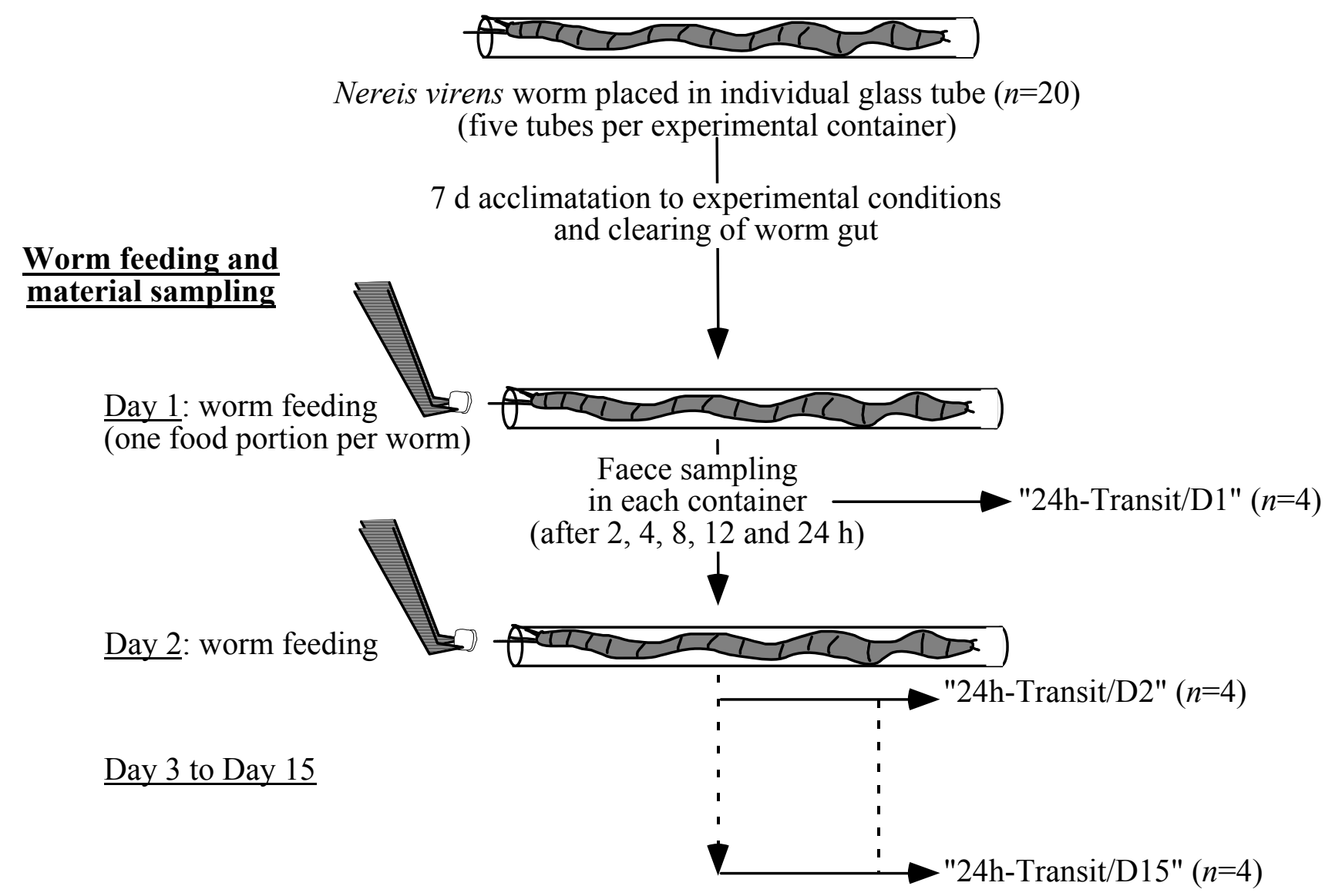

Figure 1: Experimental procedure. The various steps are described in detail in text. 
In an additional container, in order to evidence possible non-worm related changes in tracer composition, e.g. induced by dissolution, four food portions were subjected to experimental conditions for 24 hours to serve as control. The four "24h-Controls" were then collected and separately frozen.

- Hydrocarbons analysis : The hydrocarbons were extracted from each crushed material (faeces, mucus or gut) by maceration in $10 \mathrm{ml}$ of dichloromethane and sonication for $15 \mathrm{~min}$. The mixture was then centrifugated at $7000 \mathrm{~g}$ for $10 \mathrm{~min}$ and the supernantant filtered (Whatman GF/C). This extraction procedure was repeated three times for each sample. The three fractions collected were pooled and dichloromethane was removed by evaporation. The dried sample was redissolved in $1 \mathrm{ml}$ hexane and loaded into a conditioned solid sorbent cartridge. The mini chromatographic column Alumina N Sep-Pak ${ }^{\circledR}$ Plus Cartridge was pre-conditioned by successive elutions of toluene $(10 \mathrm{ml})$ and hexane $(10 \mathrm{ml})$. The aliphatic hydrocarbons were then eluted with $10 \mathrm{ml}$ of hexane and analysed by GC/MS (5970 B HP, SPB-5 Supelco capillary column, temperature program ${ }^{16}$ ) using $n$-eicosane as internal standard.

- Data analysis : Differences between materials were studied using a one-way analysis of variance (ANOVA). Bartlett's test was employed to test for homogeneity of variance. Heteroscedastic data were transformed and then evaluated using ANOVA.

\section{RESULTS AND DISCUSSION}

In this paper, we presented the results obtained after 15 days, corresponding to the end of the feeding experiment. Figure 2 illustrates recovery percentage of the different compounds ( $n$-alkanes, pristane and androstane) from the initial tracer (food portion), in the 24h-Control and the 24h-Transit/D15 materials (faecal material sampled during $24 \mathrm{~h}$ after worm feeding, for the $15^{\text {th }}$ day of experiment).

Results showed first that all the compounds of the initial tracer (food portion) were present in 24h-Control and in faeces. However, it appeared that the distribution of the $n$-alkanes changed with the experimental conditions. After a $24 \mathrm{~h}$ stay in the seawater (24h-Control), the distribution of $n$-alkanes indicated a loss of compounds in the food portion. The loss was greater for the low molecular weight $n$-alkanes (LALK ${ }^{17}$ ) than for the heavy molecular weight $n$-alkanes (HALK) (Table I) and could be explained by dissolution and volatilization, the food portions floating at the water surface. On the other hand, on the 15 th day of experimentation, the change in the tracer composition induced by ingestion of the initial tracer by worms was different. An increased loss of the low molecular weight compounds ( $n$-alkanes from $n-\mathrm{C}_{14}$ to $n-\mathrm{C}_{18}$ and pristane) was apparent in the $24 \mathrm{~h}$ sampled faeces, whereas the differences measured for the highest molecular weight $n$-alkanes (from $n$ - $\mathrm{C}_{22}$ to $n$ - 
$\mathrm{C}_{29}$ ) were slight, resulting in greater decrease of LALK/HALK ratios (Table I). Moreover, the $n$-C17/Pr ratio, a diagnostic ratio used to study the biodegradation of hydrocarbons $8,9,18$, which was calculated from the $24 \mathrm{~h}$ Control and 24h-Transit/D15 samples was significantly different. For both materials, the increase of the $n$ $\mathrm{C} 17 / \mathrm{Pr}$ ratio ran counter the evidence of the bacterial degradation of hydrocarbons ${ }^{19}$, though this was less marked for the $\quad 24 \mathrm{~h}-$ Transit/D15 samples.

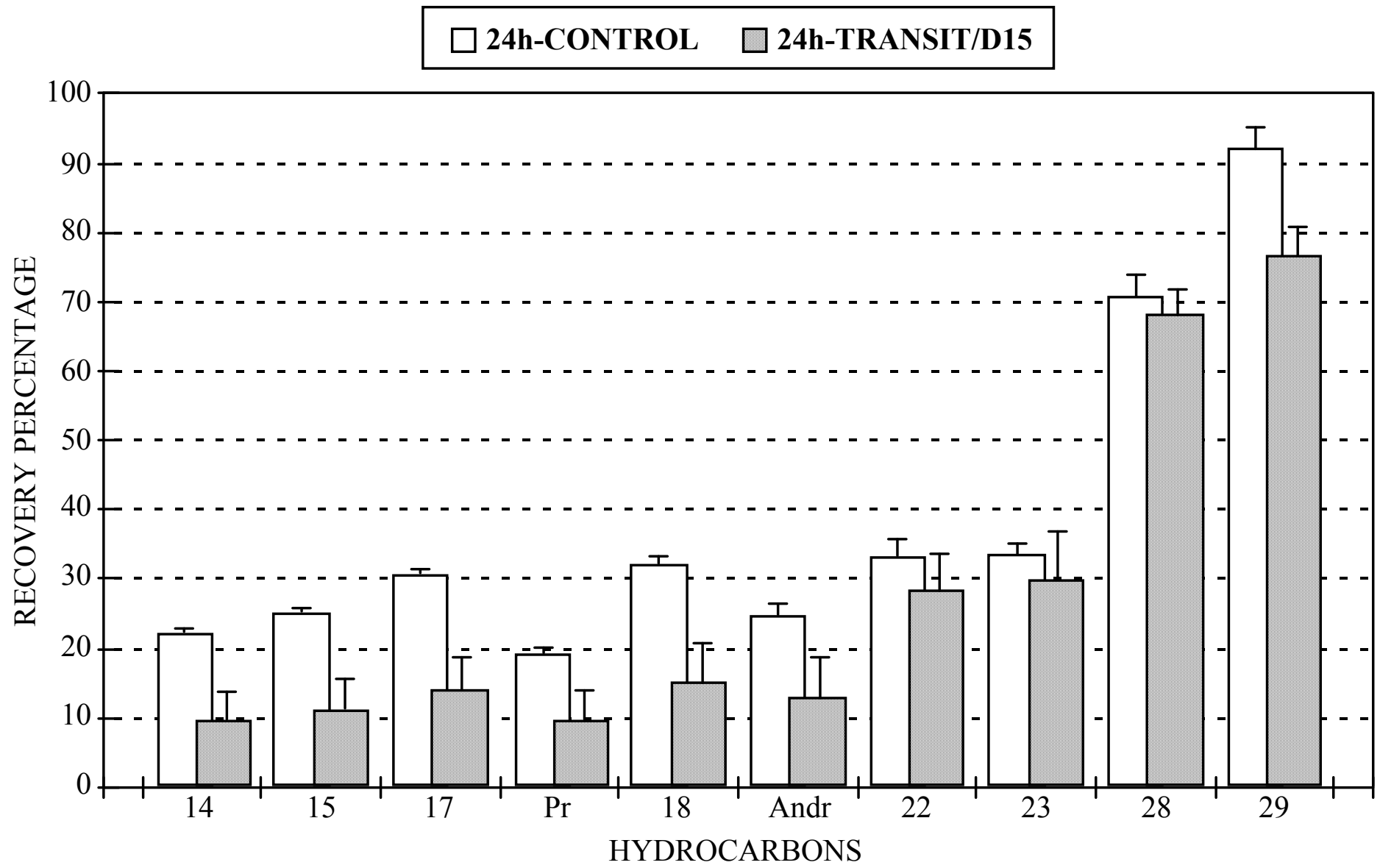

Figure 2: Recovery percentage of the various compounds from the initial tracer (food portion) in the different experimental material samples. Standard errors appear above the mean values $(n=4)$. $24 \mathrm{~h}-$ Control: food portion submitted to experimental conditions for 24 hours in absence of worms; 24h-Transit/D15: faeces sampled during $24 \mathrm{~h}$ in a container containing four Nereis virens, after the ingestion of one food portion per worm, for the $15^{\text {th }}$ day of experiment). Numbers refer to carbons in $n$-alkanes $\left(n-\mathrm{C}_{14}\right.$ to $n$ - $\left.\mathrm{C}_{29}\right)$; Pr: pristane; Andr: androstane.

However, we should bear in mind that a recent work has demonstrated that the use of this $n$-alkane/isoprenoid ratio may be limited in certain experimental conditions ${ }^{20}$. 
The alteration in the $n$-alkane tracer composition in the faece samples could then be not solely related to the dissolution and volatilization of compounds during the stay of faeces in seawater $(<12 \mathrm{~h})$ but might be in part due to the impact of the worm's digestif process involving :

- stimulation of the dissolution process induced by the gut transit;

- preferential adsorption of compounds in the worm gut;

- chemical or/and biological attack on the compounds in the worm gut as demonstrated with aromatic hydrocarbons $7,12-14$;

- and, though classical specificity in the possible compound microbial biodegradation ${ }^{21}$ was not indicated by the study of the $n-\mathrm{C} 17 / \mathrm{Pr}$ ratios, the development of a hydrocarbonoclastic microflora and the biodegradation of coumpounds in the worm gut and/or biodegradation occurring in the faeces.

\section{Table I}

LALK/HALK and $n$-C17/Pr ratios of the hydrocarbon $n$-alkanes composition calculated from the different materials. ANOVA analysis (for 4 replicates) comparing the values indicates a significant difference between the three types of material for both ratios $(\mathrm{P}<0.001)$. For the name of each material, see text. LALK: Low molecular weight $n$-alkanes $\left(n-\mathrm{C}_{14}, n-\mathrm{C}_{15}, n\right.$ - $\mathrm{C}_{17}, n$ - $\left.\mathrm{C}_{18}\right)$; HALK: heavy molecular weight $n$-alkanes $\left(n\right.$ - $\mathrm{C}_{22}, n$ $\left.\mathrm{C}_{23}, \quad n-\mathrm{C}_{28}, n-\mathrm{C}_{29}\right)$; Pr: pristane.

\begin{tabular}{|c|c|c|c|}
\hline & Initial Tracer & 24h-Control & 24h-Transit/D15 \\
\hline LALK/HALK & $0.91 \pm 0.2$ & $0.73 \pm 0.2$ & $0.42 \pm 0.4$ \\
\hline$n-\mathrm{C} 17 / \mathrm{Pr}$ & $0.67 \pm 0.1$ & $1.12 \pm 0.3$ & $0.90 \pm 0.4$ \\
\hline
\end{tabular}

The first result presented in this paper demonstrates the direct role of the Nereis virens digestive process in the fate of hydrocarbons in the sediments, passage through the worm gut altering the composition of the hydrocarbon mixture tracer in a different manner than would physical processes of compounds alone. Further complementary results might make it possible to determine whether hydrocarbons are stored in worms and whether the process demonstrated after 15 days of experimentation varied with the time the worms are exposed to hydrocarbons. 


\section{ACKNOWLEDGEMENTS}

The authors are grateful to Diane "S.O.S. GC/MS" Bérubé for her kindness. This work was carried out as part of the G.R.E.C. (Groupe de Recherche en Environnement Côtier, UQAR, Québec, Canada) and the G.D.R. "HYCAR" (Groupement De Recherche n²1123, CNRS - Universities - Société Elf Aquitaine, France) and was supported by a grant from the Société de Secours des Amis des Sciences (to Franck Gilbert) and by grants from the Natural Sciences and Engineering Research Council of Canada (CRSNG) to Gaston Desrosiers and JeanPierre Gagné.

\section{REFERENCES}

1- H. III LEE and R. C. SWARTZ, in "Contaminants and Sediments, Vol. 2, Analysis, Chemistry, Biology", Ed. R. A. Baker, Ann Arbor Science Publish., Ann Arbor, p. 555 (1980).

2- T. B. REYNOLDSON, in "Ecological Effects of In Situ Sediment Contaminants", Eds. R. Thomas, R. Evans, A. Hamilton, M. Munawar, T. Reynoldson and H. Sadar, Dr W. Junk Publishers, Dordrecht, The

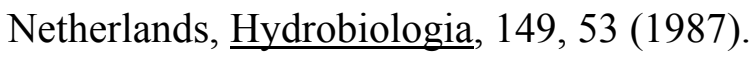

3- D. C. GORDON Jr, J. DALE and P. D. KEIZER. J. Fish. Res. Board Can., 35, 591 (1978).

4- S. W. KARICKHOFF and K. R. MORRIS. Environ. Sci. Technol., 19, 51 (1985).

5- W. S. GARDNER, R. F. LEE, K. TENORE and L. W. SMITH. Wat. Air Soil Pollut., 11, 339 (1979).

6- J. E. BAUER, R. P. KERR, M. F. BAUTISTA, C. J. DECKER and D. G. CAPONE. Mar. environ. Res., 25, 63 (1988).

7- A. E. McELROY, J. W. FARRINGTON and J. M. TEAL. Environ. Sci. Technol., 24, 1648 (1990).

8- F. GILBERT, L. RIVET and J-C. BERTRAND. Chemosphere, 29, 1 (1994).

9- F. GILBERT, G. STORA and J-C. BERTRAND. Chemosphere, 33, 1449 (1996).

10- A. MYERS. J. mar. Res., 35, 609 (1977).

11- C. PLANTE and P. JUMARS. Microb. Ecol., 23, 257 (1992).

12- R. LEE, S. C. SINGER, K. R. TENORE, W. S. GARDNER and R. M. PHILPOT, in "Marine Pollution: Functional Responses", Eds. V.B. Vernberg, F.P. Thurberg, A. Calabrese, F.J. Vernberg, Academic Press, New York, 23 (1979).

13- A. E. McELROY and J. D. SISSON. Mar. environ. Res., 28, 265 (1989). 
14- V. E. FORBES, L. F. FORBES and M. HOLMER. Mar. Ecol.-Prog. Ser., 132, 63 (1996).

15- M. OLIVIER, G. DESROSIERS, A. CARON, C. RETIERE. Mar. Biol., 125, 693 (1996).

16- F. GILBERT, G. STORA, P.BONIN, Y. LEDRÉAU, G. MILLE and J-C. BERTRAND. Hydrobiologia, In press.

17- M. S. STEINHAUER and P. D. BOEHM. Mar. environ. Res., 33, 223 (1992).

18- J. G. LEAHY and R. R. COLWELL. Microbiol. Rev., 54, 305 (1990)

19- M. BLUMER, M. EHRHARDT and J. H. JONES. Deep Sea Res., 20, 239 (1973).

20- Y. LEDRÉAU, F. GILBERT, P. DOUMENQ, L. ASIA, J-C. BERTRAND and G. MILLE. Chemosphere, In press.

21- R. M. ATLAS. Microbiol. Rev., 45, 180 (1981). 